\title{
Environmental disasters in social context: toward a preventive and precautionary approach
}

\author{
Kenneth Hewitt
}

Received: 18 January 2012/Accepted: 17 April 2012/Published online: 12 June 2012

(C) Springer Science+Business Media B.V. 2012

\begin{abstract}
The paper examines relations between natural hazards and social conditions in disaster, and problems of their integration in disaster management. This must be done against a background of ever-increasing numbers of disasters. The initiating roles and impacts of environmental hazards are acknowledged. However, expanding losses are not explained by increased geophysical risks. To the extent that scientific knowledge or engineering and planning skills are involved, the problems seem more one of (in)effective deployment than major deficiencies. Social analyses suggest the scope of today's disasters follows primarily from greater concentrations of vulnerable people, exposed in dangerous situations, and lacking adequate protections. Firstly, the question of disaster causality is revisited as a problem of damage diagnostics. A basis is developed from the findings of formal disaster inquiries. Despite their limitations, well-conducted inquiries offer unusually comprehensive anatomies of the social and physical conditions of disasters. They demonstrate and trace out the interplay of environmental, societal, technological, and institutional components of emergencies. In the examples described, environmental hazards are investigated in great detail. Nevertheless, societal preconditions are shown to be more critical. Inadequacies in emergency preparedness, performance, and post-disaster response are highlighted, and for those most at risk. The conclusions present major challenges for the agent-specific view of disasters, and for disaster management preoccupied with natural forces, uncertainty, and emergency responses. Rather, a view of disaster causality emerges emphasizing avoidable failures of preventive, protective, and intervention measures. Evidence is cited to show this is increasingly relevant in so-called natural disasters lacking such inquiries. The discussion considers the relevance of a preventive and precautionary approach in this context. The histories of accident, disease, fire, and crime prevention support arguments for greater attention to context-specific environmental and societal aspects of risk. Aligning disaster management more closely with preventive priorities depends upon a much greater focus on people, places, and livelihoods most at risk, reversing the social processes that put them at risk. It requires listening to their voices and concerns, recognizing and bolstering their resilience. Much more can and
\end{abstract}

K. Hewitt $(\bowtie)$

Wilfrid Laurier University, Waterloo, Canada

e-mail: khfornh@gmail.com 
should be done to disseminate the protections, from building regulations to insurance, that actually do save so many others in the disasters that happen. As such, the case for greater attention to issues of governance and social justice is strengthened.

Keywords Disasters $\cdot$ Vulnerability $\cdot$ Social context $\cdot$ Environmental risk

\section{Introduction}

...nature can no longer be understood outside of society, or society outside of nature... (Beck 1992, 80)

Scientists investigating natural hazards, whether tsunami or near-Earth objects, flood probabilities or slope stability, are well aware of research gaps and the value of pursuing promising new methods. Practitioners welcome improvements in science-based monitoring and forecasting of environmental extremes. In fact, research has already brought an unprecedented level of knowledge about the planetary environment. Monitoring capabilities and forecasting networks exist for a host of potentially dangerous phenomena and are constantly being refined. Even so, it is generally agreed that the numbers of "natural" disasters worldwide, and losses in them, have been growing in relative as well as absolute terms for a century or more (UNDP 2004; EM-DAT 2012). Some places and activities do have remarkably successful safety systems; they seem more secure and reliable than any time in the past. In so many other places, however, disaster risks seem to outstrip response capacities.

With the exception of some climate-related conditions, increasing geophysical risk cannot be demonstrated. Even in the case of atmospheric hazards, the geophysical dimensions of the worst events in recent years had been equaled or exceeded in previous centuries. With the scientific consensus seeing human activity as the main driver of ongoing climate change, the only options to effectively reverse it also depend upon social change.

In general, social assessments show that increased dangers come mainly from greater human exposure and vulnerability, or absent protections. Population increase is commonly cited as the core of the problem, and loss potential does involve exponential growth in numbers. The growing intensity of economic activity adds to this, especially concentration in ever-larger urban agglomerations. However, it is doubtful there is a simple relation to numbers or growth. Consider such findings as:

...While only 11 percent of the people exposed to natural hazards live in low human

development countries they account for more than 53 percent of recorded deaths.

Development status and disaster risks are clearly closely linked... (UNDP 2004, 10)

Meanwhile, for decades and in nearly all countries, the production of wealth per capita and availability of modern products have outstripped population growth. Access to wealth and modernization can have positive effects on safety measures, but major disasters still occur in the wealthiest countries as residents of New Orleans, and Fukushima, Japan can testify.

The role of conditions other than sheer numbers is seen in two lines of evidence: the disproportionate death tolls and material losses in particular places, or among particular groups of people, and the reports of damages for which well-known, even mandated protective measures were not provided. 


\section{Indiscriminate forces, "discriminating" damage}

In the scientific view of earthquake, storm, or flood, the forces involved are seen to depend mainly on geophysical conditions, but to be indiscriminate in human impact. So, why are damage and death in disasters not indiscriminate?

"Discriminatory" losses appear in the exceptional numbers of women killed in communities around the Indian Ocean by the 2004 tsunami and of women and the elderly in the Kobe 1995 earthquake. There was the extraordinary spatial concentration of death and destruction in one part of Mexico City in the 1985 earthquake, $450 \mathrm{~km}$ from the epicentre (Hewitt 2007). Social explanations of such disproportionate losses relate them to specific historical and cultural conditions, and modern developments that put some at greater risk than others (Enarson and Morrow 1998). When looking at actual settings, the largest losses tend to identify relatively impoverished and powerless groups, but also particular developments in human settlement, most obviously those in and around rapidly growing urban centers (Maskrey 1989; Fernandez 1999; Pelling 2003a, 2003b).

Details of losses not only underscore the vulnerability of particular groups, sectors and areas, but puzzling and unacceptable cases. Of special concern for professional response are reports of modern safety standards ignored or unenforced. The lethal building collapses in earthquakes at Izmit, Turkey in 1999 and Bhuj, India in 2001 could, apparently, have been prevented, if established standards and national building codes had been enforced (World Bank 2001; Ozerdem and Jacoby 2006). There is fairly convincing evidence that many thousands of schoolchildren killed in the Sichuan, China, 2008 earthquake, and the 2005 earthquake, northern Pakistan died in collapses of school buildings that failed to meet established building codes. In wealthy as well as poorer countries, neglect and failures in systems the public relies upon are widely reported (McClean and Johnes 2000; OliverSmith and Hoffman 2001).

On the simplest level, of course, all can agree that earthquake or wild fires are not themselves disasters. Similarly, an impoverished population in unsafe houses is not a disaster, in these terms at least. A disaster comes about from the destructive interactions of environmental hazards, peoples' exposure, vulnerability, and absent protections. With this in mind, the problem can be treated as damage profiling in disasters. At root, understanding depends upon tracing out and explaining just how damages occur, where, and to whom (IRDR/ICSU 2011). These seem to be the proper scientific basis for assigning causes and improving responses.

\section{Disaster diagnostics: an inquiries perspective}

An approach used here is a variant of Turner's (1978) method of comparative analysis of findings in pre-existing public disaster inquiries. He showed how this can identify the specifics of damage contexts and processes and overcome undue emphasis on particular hazards, disciplines and events. There are reasons for caution about formal inquiries, even those with independence and broad scope. Nevertheless, the levels of public investment and involvement can allow a degree of comprehensive coverage and diagnostics otherwise not available. The type, size, or location of disaster is not immediately important, but rather the process and results. A singularly thorough Canadian inquiry serves to introduce the approach. It will then be compared with a larger set and what relevance it might have to so-called natural disasters generally. 
In May, 2000, a severe outbreak of disease affected at least 2,321 residents of Walkerton, a small town in southern Ontario. There were seven deaths. Many people continued to suffer related illness and distress years later. It was not one of the world's great disasters, but the two-volume inquiry report offers a compelling disaster profile (O'Connor 2002). A summary of the main points and findings must suffice (Table 1).

Walkerton is also chosen because, if few now recall it as such, arguably it was a typical "natural disaster." The event followed from a heavy rainstorm. Without the May 10-12 rain, or had it been smaller-no disaster. Without fields saturated from melting of heavy winter snowfall, it is likely no disaster would have occurred, or not then. The cause of illness and death was shown to have been Escherichia coli 0157:H7 in drinking water with, possibly, some cases of Campylobacter jejuni. Unfavorable geological conditions at Well \#5, where contaminated runoff entered the town's water supply, were critical; intervening or secondary hazards found in most environmental disasters.

The inquiry spent most time on these technicalities and reconstructing each phase of the disaster. It included extensive technical analyses, from meteorological, hydrological, and geological supplementary reports to use of DNA and epidemiology to identify pathogen sources, pathways, and victims. Testimony was taken from experts in relevant fields, officials on the spot, and residents. Weather, hydrology and pathogens were accepted as important agents; the hazards that triggered and caused the critical damage in the disaster. Nevertheless, the inquiry did not identify them as fundamental causes. Rather, it concluded that the harm they did could and should have been prevented-shifting the explanation onto societal conditions.

Table 1 Summaries of the elements and findings of the Walkerton tragedy and inquiry which serve to illustrate the sorts of issues that need to be covered in a diagnostic profiling of disasters (after O'Connor 2002)

\begin{tabular}{|c|c|c|}
\hline Phase & Natural agents/hazards & Societal/technol. conditions \\
\hline Preconditions & $\begin{array}{l}\text { Adverse rock formations and drainage paths } \\
\text { allow ready infiltration of contaminated } \\
\text { water into aquifer around and into Well } 5 \\
\text { (Escherichia coli } 0157: \mathrm{H} 7 \text { and } \\
\text { Campylobacter jejuni have months-long } \\
\text { survival in soil, especially if turned or } \\
\text { flushed into lower layers) } \\
2000 \text { Wet spring, Saturated soils } \\
\text { Heavy rain May 10-12 }\end{array}$ & $\begin{array}{l}\text { (i) Water quality, pollution, Conservation } \\
\text { movement, } \\
\text { (ii) Ontario, } 1978 \text { advisory on land-use to } \\
\text { protect water sources, } \\
\text { (iii) } 1992-1998 \text { budget cuts to MOE; } \\
\text { government downsizing, outsourcing } \\
\text { agendas } \\
\text { (iv) } 1996 \text { limiting or closing government } \\
\text { testing lab's; reporting requirement of } \\
\text { adverse tests not continued. } \\
\text { (v) } 1998 \text { MOE report cites problems with } \\
\text { Well } 5 \text { and chlorination system } \\
\text { (vi) } 2000 \text { winter manuring of fields near } \\
\text { Well } 5 \text {. Manure heavily contaminated by } \\
\text { E. coli and C. jejune. Soil turned over } \\
\text { immediately, helping survival of bacteria }\end{array}$ \\
\hline The disaster & $\begin{array}{l}\text { May } 17-25,2321 \text { residents treated for } \\
\text { severe illness; } 7 \text { deaths among children, } \\
\text { elderly, immune-impaired. } \\
\text { Eventual relief operations included } \\
\text { provision of household drinking water, } \\
\text { medical care, counseling }\end{array}$ & $\begin{array}{l}\text { Municipality had a "Disaster plan," but did } \\
\text { not invoke it }\end{array}$ \\
\hline Aftermath & $\begin{array}{l}\text { Among residents: ongoing illness, some to } \\
\text { the present time; }\end{array}$ & $\begin{array}{l}\text { Distress, outrage at clear failure of } \\
\text { responsible officials made public, an } \\
\text { official apology issued. }\end{array}$ \\
\hline
\end{tabular}


In the end, the disaster was attributed to a series of failings, operational omissions, and negligence in relevant safety systems and responsible organizations. Established water safety requirements and problems were ignored or misrepresented (Table 2). In this, the importance of looking at conditions that long pre-dated the disaster was shown, and at matters that extended well beyond its geographical boundaries. The history and requirements of safe public water supply were carefully scrutinized. It required a crucial shift in focus from hazardous agents to a singular form of vulnerability. Some people were also unusually vulnerable for pre-existing medical reasons, notably those who died. However, the entire community was made vulnerable through its trust in the safety of drinking water, when key institutions and professional practices had been unraveling on several levels.

The failings found at Walkerton are far from unfamiliar in social contexts. However, in "natural disasters," if recognized at all, they tend to be treated as local, subjective, ad hoc or "human failings" and "accidents" rather than, as for the inquiry, keys to the underlying causality of disaster. It is here that Turner's comparative approach is valuable.

\section{Other inquiries and their findings}

... what happened on the afternoon of the power failure [heat wave and high demand] was not a cause in itself. Rather, deficiencies in corporate policies, lack of adherence to industry policies, and inadequate management [were responsible]... US-Canada 2003 Power System Outage Task Force (2004, 18, emphasis added)

The significance of the Walkerton findings is reinforced by a range of similar conclusions from other inquiries that, otherwise, differ greatly in size, place, and hazards (Table 3). Most give thorough and detailed accounts of the hazards, damages, and professional assessments involved; more or less extensive longitudinal profiles of preconditions, the handling of the emergency and post-disaster actions. Again, however, they end up attributed the disasters substantially or wholly to failures by or in the relevant safety systems, responsible personnel and organizations, often a broader climate of eroding safety priorities.

Expert analyses and investigations of environmental conditions or processes led to the conclusion that many or all losses could and should have been prevented. Typically,

Table 2 Some significant conclusions of the Walkerton inquiry that put the onus on preventive and protective issues

1. "... if the Ministry of the Environment had adequately fulfilled its regulatory and over-sight role, the tragedy in Walkerton would have been prevented ... or at least significantly reduced in scope." (O’Connor 2002)

2. “Two serious failures ... [and] a host of improper practices... on the part of the Walkerton PUC operators directly contributed to the outbreak...” (pp. 182-183)

3. "At the Inquiry, the government argued that I should find [the PUC operator] was the sole cause of the tragedy... [and] that government failures, if any, played no role... I reject that argument completely..." (268)

4. “...The story of the outbreak involves much more than a description of the clinical symptoms of the illnesses, the medical treatment, and the numbers of people who became ill and died. Most important are the stories of the suffering endured by those who were infected; the anxiety of their families, friends and neighbors; the losses experienced by those whose loved ones died; and the uncertainty and worry about why this happened and what the future would bring." (Ibid, I, 5) 
Table 3 Other disaster inquiries consulted

They were chosen for the commitment to investigating the damages, for having addressed questions of cause and prevention, not because of their relative size, the hazards involved or geographical location
1. Blackout, US and Canada, August 14th, 2003

2. SARS outbreak, Ontario, 2002-2003

3. Contaminated drinking water, Walkerton, Ontario, 2000

4. Estonia' ferry sinking, Baltic Sea, 1994

5. Westray mine explosion, 1992

6. Tainted' blood scandal, Canada, 1980s-1990s

7. BSE outbreak, UK 1990s

8. School massacre, Dunblane, Scotland;

9. Hillsborough soccer stadium crush, 1989

10. "Marchioness" pleasure boat sinking, London, UK, 1989

11. Dryden, Air Ontario crash, 1989

12. "Piper Alpha" oil rig explosion and fire, 1988

13. "Herald of Free Enterprise" ferry sinking, Zeebrugge, 1987

14. "Ocean ranger" drilling rig loss, Grand Banks, 1982

15. Teton Dam failure and flood, Idaho, USA, 1976

16. Buffalo Creek flood, West Virginia, 1972

17. Aberfan coal tip collapse, S. Wales, U.K., 1966

18. Tenerife, aircraft collision,

pre-event safety conditions had been misrepresented, known security problems ignored. A particular concern is how often recommendations of previous inquiries would have been sufficient to prevent the later disasters-if they have been followed.

Another way to describe these results is in terms of several distinct types of disaster, albeit interrelated, in what appear as single events. Partly this arises from the willingness to investigate pre- and post-disaster conditions, but also in the broader environmental contexts. The various conclusions characterize most of the events by one or more of the following (Table 4):

1. Disaster of (failed) preventive measures

2. Disaster of poor or failed intervention measures

3. Disaster of inappropriate or failed recovery measures

4. Failures to implement recommended safety measures

These forms of disaster classification or explanation are very different from what prevails in the natural disasters field, and one must ask whether cases like Walkerton are relevant more generally. Do the inquiries have any relevance in this case?

Table 4 Major findings of disaster causes based on inquiry conclusions

\begin{tabular}{ll}
\hline Causal class & Cited in inquiry findings* \\
\hline Disaster of (failed) preventive measures & All \\
Disaster of failed intervention measures & $2,3,5,6,9,11,12,13,14,17,18$ \\
Disaster of failed recovery measures & $2,3,6,7,9.10,12,13$ \\
Failure to implement recommended safety measures & All \\
\hline
\end{tabular}

*(Erikson 1976; Evans 1987; Hartley 2001; Hewitt 1983; Oliver-Smith 1986; OPHA 2003) 


\section{Un-natural disasters}

Disasters often involve regulatory failures. Somebody was responsible for safety and failed to ensure it, through negligence or lack of imagination, or both. (McClean and Johnes 2000, 220)

If a disaster is triggered by a geophysical event, or most losses are attributed to geo- or biophysical forces, it seems the planetary environment and natural hazards will be held responsible. In conventional views, human and institutional failures appear as the very opposite of the "natural hazards paradigm" (Gilbert 1998) or "Acts of God" (Steinberg 2000).

Suppose, however, much of the damage following a natural trigger is caused by other factors-say, the post-earthquake fires in San Francisco, 1906 and at Kobe, 1995, or the post-tsunami nuclear explosions and contamination at Fukushima. How far can and should such events be understood as "natural" disasters? More importantly, suppose much or all of the damage can be shown to have been preventable, as at Walkerton, then, it seems the causal and practical focus has to shift to secondary hazards and societal risk, which tend to be peculiar to the pre-existing social and land-use settings.

In fact, as noted above, reports from many recent disasters offer compelling evidence of the role of social conditions, especially in disproportionate losses for particular places and groups of people (Hewitt 2007). While earthquake, tsunami, and storms are indiscriminate, losses in the disasters associated with them rarely are. Even in wealthier countries, careful assessments reveal some major, avoidable losses, essentially among the less well-off, or due to institutional and technical failures. Reports suggest these were substantial if not dominant factors in Hurricane "Katrina" losses, in the 2011 earthquake and tsunami in Japan and December floods in Queensland, Australia, and in the 2010 Christchurch, New Zealand earthquake. Where detailed inspection of specific forms and conditions of harm are available, the reader will have difficulty finding an environmental disaster of, say, the last 50 years anywhere, in which major if not most losses were not preventable (Table 5). Detailed reconstructions show many victims had been living in areas and buildings, which pre-disaster surveys showed, or would have shown, to have violated elementary safety rules. A majority were reported as already suffering from a range of acute stresses and lack of basic supports before the disasters.

Another misleading view is that disasters mean wall-to-wall and indiscriminate damage determined only by the forces of Nature. Instead, all these disaster zones also had people, structures, and services that survived, and not through sheer luck. They benefitted from safer sites and other precautions. An extraordinary example is the extent of neighborhoods and structures that remained unharmed in the city of Kobe in the Great Hanshin earthquake, practically next door to the worst losses (Hewitt 2007). In such cases, robust survivals are the best measure of what went wrong or was missing where damages did occur.

In the absence of the intensive profiling available for the inquiries, it cannot be said what fraction of losses fit one or other of the various types or explanations of disaster. Then again, the evidence for unavoidable or unstoppable damage is rarely detailed and often, also, only presumed. It does seem fair to focus on losses in disasters that reflect people at risk through conditions in which society intervenes adversely or could intervene beneficially and fails to do so. 
Table 5 Examples of disasters with natural hazards triggers where sources of some or all deaths and damages were attributed to institutional failures, ignored or unenforced safety measures, and social preconditions that exposed unprotected populations

\begin{tabular}{|c|c|c|}
\hline & Disaster & Location and date \\
\hline 1 & Earthquake disasters: & $\begin{array}{l}\text { Sichuan, China, 2008; Kashmir, India and Pakistan, 2005; Sumatra, } \\
\text { 2005; El Salvador, 2001; Gujarat, India, 2000; Turkey, 1999; } \\
\text { Kobe, 1995, Lomo Prieta, 1989: Armenia, 1988; Mexico City, } \\
1985\end{array}$ \\
\hline 2 & Flood disasters & $\begin{array}{l}\text { Buffalo Creek flood, West Virginia, 1972; Grand River, Ontario, } \\
\text { 1974; Teton Dam failure and flood, Idaho, USA, 1976; Quebec } \\
\text { flood, 1996; Indus valley, Pakistan, September 1992; North } \\
\text { Wales, 1990; El Salvador, } 2005\end{array}$ \\
\hline 3 & Tsunami & Indian Ocean, 2004; Japan, 2011 \\
\hline 4 & Hurricanes & $\begin{array}{l}\text { “Andrew" Florida, 1992; "Mitch”, Central America, 1998; } \\
\text { "Jeanne" US and Caribbean, 2004; "Katrina", New Orleans and } \\
\text { Gulf coast areas, } 2005\end{array}$ \\
\hline 5 & Droughts & $\begin{array}{l}\text { Dust Bowl 1929-1941; US and Canadian West 1952-1957, } 1962 \\
\text { 1972, 1974-1982, and 1988; all Indian sub-Continent droughts of } \\
\text { the 20th Century; Horn of Africa, } 2011\end{array}$ \\
\hline 6 & Wildfires & $\begin{array}{l}\text { Oakland, California wildfire, 1991; S. California, 2007, 2009; } \\
\text { Indonesia, 1982-1983, 1986, 1991, 1994; 1997-1998; 2011; } \\
\text { Okanagan Valley, BC. 2003 ; Portugal, 2003; Victoria, Australia, } \\
\text { 2009; Mediterranean France, Greece, Italy, Spain, } 2009\end{array}$ \\
\hline 7 & $\begin{array}{l}\text { Disease outbreaks from } \\
\text { contaminated water supply }\end{array}$ & Milwaukee, 1993; Walkerton, 2000; (Cholera) W, Kenya, 2008 \\
\hline 8 & Anthrax outbreak & Sverdlovsk, USSR, 1976 \\
\hline 9 & Iceberg hazard: & Titanic sinking, 1912 \\
\hline
\end{tabular}

\section{Social vulnerability and capacities}

It is in such terms that social scientists commonly find that the scope of today's disasters indeed follows from greater concentrations of vulnerable people, exposed in dangerous situations and lacking adequate protections (Blaikie et al. 1994). These appear to be the main reasons why more disasters are being caused by smaller geophysical events, or greater devastation in less extreme parts of large ones (Etkin 1999). Social analyses suggest that modern development and social upheavals have brought multiplying risks, notably in relation to urbanization, resource extraction, megaprojects, commercialization of agriculture, and unfair international trade (Middleton and O'Keefe 1998; Bankoff et al. 2003; Coelho 2007). They involve a worsening of conditions through inequities and prejudice by wealth, class, (un)employment, gender, ethnicity, religion, etc.. One finds these predicaments commonly arise in combination with militarization, enforced displacement, legal and illegal arms trade. They can lead to an increase in "complex emergencies"; disasters involving social upheavals and violence as well as environmental and medical calamity (Bohle 1993). It no longer makes sense to separate off a domain of "natural" from other types and causes of disaster, much as the quotation from Beck (1992) implies.

The most vulnerable people are those whose capacities and freedom to act are normally limited or deliberately suppressed, and in multiple ways. The space of disaster risk is rooted in social justice or its absence. Vulnerability can change dramatically with social or 
habitat changes, hence the key relation of development to disasters (Pelling 2003a, 2003b; Bankoff et al. 2003). Development risks frequently have the same social distribution as benefits, but in inverse relations (Middleton and O'Keefe 1998).

Moreover, vulnerability is a social dynamic not a passive or inevitable condition awaiting an impact. As in any decent family or group, more vulnerable members-small children, the elderly, or infirm-can receive exceptional care and protections. Given the opportunity, vulnerable people are very creative in finding ways to reduce risk (Delica 1998; Yonder 2005). This capacity is referred to as "resilience" (IFRCRCS 2004). It requires an appropriate balance of self-reliance and entitlements, which society can encourage or deny. Such conditions require a focus on vulnerable people and more widespread promotion of safe practices, hence the growing emphasis on "mitigation strategies" by international and regional organizations (Lavell 1994; Mileti 1999; UNDP 2004; Haque 2005).

\section{Discussion: precautionary and preventive agendas?}

“...the engineering sciences face an historic turning point; they can continue to think and work in the worn-out ways of the nineteenth century... Or they can face the challenges of a genuine, preventive management of risks. Then they must rethink and change their own concepts of rationality, knowledge and practice..." (Beck 1992, p. 71 underline added)

Many of the deaths and most damages in recent disasters did not arise from unprecedented or unstoppable natural forces, but a lack of otherwise known and available protections. Some are direct, others depend upon access to timely warnings, avoidance of destructive outcomes, or prudent cushions that help people to recover from losses. Far from being about unprecedented natural calamities, closer parallels are with the problem of urban fires, communicable diseases, transport and industrial "accidents," one or two centuries ago. As such, the most necessary and promising steps lie in social initiatives inspired by those that have had such dramatic impacts in areas of product safety, disease, accident, crime, and fire protection. It suggests that precautionary and preventive measures in and for the places at risk are needed to balance an undue dependence on external, heroic emergency interventions.

In practice, when disaster prevention is mentioned, many colleagues reject it as "unrealistic." This is to take the term out of context and ignore what has occurred elsewhere under preventive culture. Accidents, epidemics, mass fires, and crimes have not ceased to happen. Where they are on the increase, they certainly challenge the preventive approach. However, it is the mind-set, focus, and goals that are important. Moving environmental disasters work in this direction would foreground assistance, protections, and preparedness ahead of emergencies, and for those persons and activities damage diagnostics reveal as most at risk. Inspiration can be drawn from fields that share proactive and preventive goals in their areas of public security, ranging from food and consumer product safety to structural, transportation, energy, and power regulation. Dramatic reductions in urban disease, mass fires, and crime helped inspire a new attitude toward accident prevention, and progress that prefigures a new logic of disaster prevention (Green 1997).

There is not space for it here, but much can be learned by tracing and emulating the progress of successful preventive fields and initiatives. They highlight how, in accident 
prevention for example, establishing the relationship between everyday practices and calamity was a fundamental step. Recommendations of the disaster inquiries cited read like public safety and accident prevention measures. Some of the professions and agencies most active and necessary in disaster response have been built up to deal with public health issues, whose ground breaking work deals mainly with preventive measures for everyday, chronic problems. Public health offers important lessons in employing the more vulnerable institutions, such as schools and hospitals to develop and promote the work of community health and hygiene. Repeatedly, by engaging women, school children, the elderly and poor neighborhoods in safety initiatives, not excluding them, it provides salutary lessons in civil care.

The precautionary principle has been articulated mainly in relation to new, potentially dangerous products. However, it can be developed as a necessary, basic principle of all forms of public security.

If disaster draws attention to specific, local pain and loss, the precursors and responses commonly involve widespread, distant and, nowadays, global human decisions and institutions that commonly ignore or run rough shod over precautionary concerns.

\section{Concluding remarks}

...Disaster prevention, mitigation, and preparedness are better than disaster response in achieving the goals and objectives of the Decade...

Yokohama Strategy and Plan of Action for a Safer World, http://nidm.gov.in/amcdrr/ yokohama, p. 2.

It is by no means suggested that investigations and improvements in the fields of natural hazards are not important, or that their deployment in avoidance strategies, warning systems and so forth should be neglected. In fact, they already are fundamental to the relative safety and security of so much of modern infrastructure, and the people and places that avoid disasters or survive them relatively unharmed. These are not, however, the essence of the disasters that do occur and are likely to occur in future-only a good indication that they could be prevented. Moreover, what one can learn and do in geophysical and other professional research will be of little use wherever social and economic pre-conditions place people at unnecessary risk or fail to implement feasible protections.

As at the Walkerton, whether an event is called a "natural disaster" is as much about perception as physical or social realities. Walkerton itself belongs to a set of events where subsequent technological and social processes were found to be more decisive than natural hazards. Other notorious examples include the "Titanic" sinking of 1908, the Tenerife aircraft collision, 1966 or Aberfan coal tip, 1996. Few would identify them, respectively, as "iceberg," "fog," or "ground water" disasters even though these hazards played critical roles.

There is a danger in "naturalizing" environmental risk; of inferring that the victims of disaster were simply at the mercy of natural forces, or somehow outside and cutoff from normal civil and societal systems. It not only ignores failures in responsible institutions, but protections that exist and are the most feasible ways to reduce and prevent losses. A preventive agenda, rather than one focused on predicting and conquering nature, would expand a role for all aspects of environmental sciences in risk reduction, rather than a preoccupation with extreme events and their natural triggers. 
All actual risk profiles are lived in the mesh of more or less inescapable social constraints, expectations, responsibilities, and happenings. Such conditions require a focus on vulnerable people and promotion of safe practices, hence the growing emphasis on "mitigation strategies" by international and regional organizations and the Hyogo Framework (Haque 2005). This is also why questions of governance, of ethical and legal assessments, are so necessary and so revealing.

\section{References}

Bankoff G, Frerks G, Hihorst D (eds) (2003) Mapping vulnerability: disasters, development and people. Earthscan, London

Beck U (1992) Risk society: towards a new modernity. Sage, London, p 10

Beck U (1999) World risk society. Polity Press, Cambridge

Blaikie P, Cannon T, Davis I, Wisner B (1994) At risk: natural hazards, people's vulnerability and disasters. Routledge, London

Bohle HG (ed) (1993) World's of pain and hunger: geographical perspectives on disaster vulnerability and food security. Freiburg studies in development geography. Verlag Breitenbach, Saarbrucken

Coelho JPB (2007) The state, the community, and natural calamities in Rural Mozambique. In: de Santos BS (ed) Another knowledge is possible: beyond northern epistemologies. Verso, London, pp 219-243

Davis I (ed) (1981) Disasters and the small dwelling. Pergamon Press, Oxford

Delica ZG (1998) Balancing vulnerability and capacity: women and children in the Philippines. In: Enarson and Morrow (eds) (1993) ch. 9. Praeger, Westport, pp 109-113

EM-DAT (2012) The International Data Base of OFDA/CRED, Universite Catolique de Louvain, Brussels, Belgium, www.cred.be/emdat

Enarson E, Morrow BH (1998) The gendered terrain of disaster: through women's eyes. Praeger, Westport

Erikson KT (1976) Everything in its path: destruction of community in the Buffalo creek flood. Simon and Schuster, New York

Etkin D (1999) Risk transference and related trends: driving forces towards more mega-disasters. Environ Hazards I:69-75

Evans RJ (1987) Death in Hoamburg: society and politics in the cholera years, 1830-1910. Oxford University Press, Oxford

Fernandez MA (ed) (1999) Cities at risk: environmental degradation, urban risks and disaster in Latin America. LA RED, The Network for social studies on disaster, Lima, Peru

Gilbert C (1998) Studying disasters: changes in the main conceptual tools. In: Quarantelli E (ed) Praeger, Westport, pp 11-18

Green J (1997) Risk and misfortune: the social construction of accidents. University College of London Press, London

Haque EC (ed) (2005) Mitigation of natural hazards and disasters: international perspectives. Springer, Dordrecht

Hartley HJ (2001) Exploring sport and leisure disasters: a socio-legal perspective. Cavendish, London

Hewitt K (ed) (1983) Interpretations of calamity from the viewpoint of human ecology. Allen and Unwin, London

Hewitt K (1997) Regions of risk: hazards, vulnerability and disasters. Routledge, New York

Hewitt K (2007) Preventable disasters: addressing social vulnerability, Institutional risk and civil ethics. Geographische Rundschau, International Edition, 3/1:43-52

IFRCRCS (2004) World disasters report: focus on community resilience. International federation of red cross and red crescent societies, Genev

IRDR/ICSU (2011) The forin project: forensic investigations of disasters, integrated research on disaster risk. International Council for Science, Beijing

Lavell A (ed) (1994) Viviendo en Riesgo: Comunidades Vulnerables y Prevencion de Desastres en America Latina. LA RED/FLACSO, Bogota

Maskrey A (1989) Disaster mitigation; a community based approach. Oxfam, Oxford

McClean I, Johnes M (2000) Aberfan: disasters and government. Welsh Academic Press, Cardiff

Middleton N, O'Keefe P (1998) Disaster and development: the politics of humanitarian aid. Pluto Press, London

Mileti GS (1999) Disasters by design: a reassessment of natural hazards in the United States. Josepg Henry, Washington, DC 
O'Connor DR (2002) Part one: a summary report of the walkerton inquiry: the events of May 2000 and related issues. Ontario Ministry of the Attorney General Queen's Printer for Ontario, Toronto

Oliver-Smith AS (1986) The Martyred city: death and rebirth in the Andes, 2nd edn. Waveland Press, Prospect Heights

Oliver-Smith AS, Hoffman SM (eds) (2001) The angry earth. Routledge, New York

OPHA (2003) Health in cities: the role for public health. Ontario Public Health Association, Toronto

Ozerdem A, Jacoby T (2006) Disaster management and civil society: earthquake relief in Japan, Turkey and India. I.B.Tuaris, London

Pelling M (2003a) The vulnerability of cities: natural disasters and social resilience. Earthscan, London

Pelling M (ed) (2003) Natural disasters and development in a globalizing world. Routledge, London

Perrow C (1984) Normal accidents: living with high risk technologies. Basic Books, New York

Quarantelli EL (ed) (1998) What is a disaster? Perspectives on the question. Routledge, New York

Sen A (1981) Poverty and famines: an essay on entitlement and deprivation. Clarendon Press, Oxford

Steinberg T (2000) Acts of god: the unnatural history of natural disaster in America. New York, Oxford

Turner BA (1978) Man-made disasters. Wykeham Publications, London

UN/ISDR (2002) Living with risk: a global review of disaster reduction initiatives. International strategy for disaster reduction, United Nations

UNDP (2004) A global report: reducing disaster risk; a challenge for development. United Nations Development Programme, Bureau of Crisis Prevention and Management, New York

Watts MJ (1983) Silent violence: food, famine, and peasantry in northern Nigeria. University of California Press, Berkeley

White GF (1969) Choice of adjustments to floods, Department of Geography Research paper No. 93, University of Chicago Press, Chicago

Wijkman A, Timberlake L (1984) Natural disasters: acts of god or acts of man?. Earthscan, London

World Bank (2001) Gujarat earthquake recovery program: assessment report. Joint World Bank and Asian Development Bank, March 14

Yonder A (2005) Women's participation in disaster relief and recovery. SEEDS Number 22, The Population Council, Inc. Washington, DC 